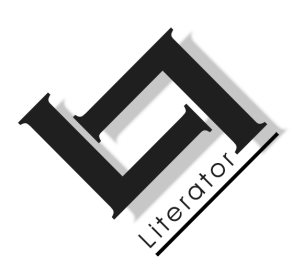

\title{
Producing subjectivities, taking risks: New directions for teaching women's poetry in South Africa
}

\author{
P.D. Ryan \\ Department of English \\ University of South Africa \\ PRETORIA \\ E-mail: ryanpd@unisa.ac.za
}

In this society the authority that teachers are empowered to grant to or withhold from student texts derives from the theory of textuality governing their reading (Linda Brodkey, 1989:125).

\section{Abstract \\ Producing subjectivities, taking risks: New directions for teaching women's poetry in South Africa}

This paper is based on five years experience of teaching an innovative poetry course at third-year level at a distance education institution. Conceived at a time when universities across the country were in the throes of academic and institutional transformation, the course departed radically from the so-called knowledge-as-accumulated-capital ethos and pointed toward assumptions initiated by Paulo Freire that knowledge can meaningfully emerge from the interaction of students from different backgrounds and asymmetrical social positions, especially when such knowledge is situated within a context which allows for creativity, self-reflexivity and critique. Most significantly, this course made available for students a forum for expressing subjectivity without the accompanying anxiety that they would be penalised for doing so. Questions are raised as to the value of presumed "objectivity" as a criterion for academic discourse, and theoretical considerations concerning the privileging of certain epistemologically suspect procedures are aired. Finally, I describe my particular contribution to the course as teacher of gender theory and show how students react to new, even revolutionary, ideas about the intersections of race and gender in relation to reading and writing about poetry. 


\section{Preface}

This paper has its beginnings in my experience of teaching a new course in poetry to third-year students of Literary Studies through the medium of distance education. The course, which was operative from 1996-2001, was something of a turning point for the people involved in teaching it and caused me to rethink both the teaching of poetry and the impact certain poems have on students.

The Department of English Literary and Language Studies at the University of South Africa (Unisa), which is a distance mode university, has been undergoing its own form of transformation (as most English departments in South Africa and elsewhere are doing) and has been researching new ways of teaching and writing course material.1] Part of the transformation has involved a recognition that the history of our department echoes to a large extent the history of the institution of which it is part. It is a history of arrogance and authoritarianism, of keeping students at a distance, not including them in the production of new courses, awarding punitive marks if they wrote subjective or emotional responses to assignment questions or if they gave a wayward interpretation of texts, of outmoded teaching methods and entrenched canonical syllabuses. In doing so, we were doing what most other institutions of learning were doing, "organising, legitimating, sustaining and refusing particular forms of student experience" (Aronowitz \& Giroux, 1991:88). We felt the need to attempt to link students' learning with their experience, to "reject the cult of knowledge, expertise and disembodied rationality that permeates the discourse of curriculum theory" (Aronowitz \& Giroux, 1991:89).

The transformation began at second level English (ENG213) with a radically subversive course called Protest, Satire and Subversion. This course took the University by storm. Everyone from the principal down began reading it with a degree of horror and fascination (no-one told the course designers to withdraw the course). The study guide included graffiti, previously banned material and a considerable amount of scatological literature. However, the course material was effective, not because of its shock value, but because it allowed students a degree of freedom hitherto unknown in the department. The third-year course I was involved in designing was called Changing Worlds, Changing Texts and built on the experiences of Protest, Satire and Subversion. From its

1 Since Unisa is a distance education institution, written course material is the main and often the only means of tuition. It is crucial, therefore, that time is spent on the most effective course design as the course remains in place for approximately five years. 
inception, the four writers of the study guide for the course were sceptical about teaching poetry by means of New Critical methodologies and a formalist ethos since it had been our experience that this approach alienated students from reading and responding to poetry. We all had areas of specialisation that we wanted to pay homage to, among them, South African literature, Gender Studies, Renaissance literature and theoretical approaches to the postmodern. After a lengthy period of brainstorming and discussion with the design team, we came up with a theme that both unified the course for the students and allowed the team members sufficient freedom to indulge in their areas of specialisation. The idea that words create worlds and worlds create words (that the world could be perceived as a text) was by no means new, but seemed a workable rationale for the course. We set out to map changing perceptions of world and text, beginning with the Renaissance period in which Mary-Helen Simpson guided students through the voyages of discovery and the concept of cartography with reference to the poetry of Donne, Sidney, Spenser, Lady Mary Wroth, Isabella Whitney, Shakespeare and other Elizabethans. Leon de Kock's seminars dealt with the mythopoeic revisioning of Southern Africa by explorers, poets, settlers and critics, taking the Adamastor myth as its key focus. Ivan Rabinowitz asked students why we read and encouraged them to "explore a different mode of investigation, a way of reading and interpreting that has a very different temporality from the conventional linear and cumulative temporality of learning". In this section, students were asked to evaluate both the usefulness of poetry and their own voyeuristic response to the poetry of desire in such poets as Walt Whitman, Allen Ginsberg and Lawrence Ferlinghetti. My seminars dealt with a gendered response to women's poetry, looking at the way in which language and visual images both define and exclude women, at the ways in which gender could be culturally constructed, at the concept of difference/s, and at women and resistance, with special reference to women of colour.

\section{Methodology of the course}

Throughout the course material, it was suggested that it was the students' responsibility to decide what to read (nothing was compulsory: both the poetry and the theoretical material were supplied in separate readers for students to browse through and to select according to their interests) and how to respond:

This course offers you a range of distinct voices and styles - like different lecturers speaking at separate venues - on the subject of changing worlds, changing texts in poetry. Our 'study guide' is unconventional. We have deliberately made it look more like a series of provisional seminar packages than a finished pedagogic product 
offering the truth for you to study. In all cases, we ask you to engage in the production of critical responses, and in the process of creating still another text - the text of your sense of meaning - in the act of reading. In this course, reading is seen as a mediation between you, with your own dispositions, idiosyncrasies and prejudices, and a text, with its own character and origin. This is the charged space into which we invite you to venture, and in which we ask you, in a sense, to find yourself (Tutorial Letter 102 for 2000:i).

Thus begins the introduction to the "study guide". Those readers familiar with critical pedagogy will recognise the underlying assumption that (following Paulo Freire) the classroom (even when in this case there is no physical classroom) need not be a site for the transmission of knowledge, of knowledge-as-accumulated-capital, but a terrain in which ideas about power and politics can meaningfully emerge from the interaction of teachers and students from different backgrounds and asymmetrical social positions. Assignment questions are open-ended, encouraging creativity and a degree of personal engagement, and the examination offers a wide choice of questions which allow for selfreflexivity, critique of the course and the importance or otherwise of poetry.

The team monitored the students' responses to this new material throughout the year and in the examination. Questionnaires were sent to students, dialogue was encouraged in tutorial letters, discussion classes took the form of interactive workshops, and students who lived far from Pretoria were encouraged to attend videotel workshops. Students were also invited to submit a project of their choice for external adjudication and it was significant that most projects submitted consisted of students' own poetry. 2

\section{Students' response}

During the early months of the course it was obvious that students did not know what was expected of them. They found the freedom unnerving, the amount of poetry and critical articles overwhelming (despite repeated statements from the course team that they were not expected to wade through all the material) and did not know how to tackle those assignment questions which called for a reading of a poem without resorting to practical criticism. They were clearly sceptical about

2 The "poetry project" as it came to be called was one of the most rewarding aspects of teaching this course. Each year we received a dozen or so projects, some of them remarkable for their originality. At the annual prizegiving, a special prize was awarded for the best project. 
our motives and disbelieving about our admonitions that they were not to treat the poem as object. Several students also objected that parts of the course seemed overwhelmingly feminist. Male students, in particular, were unprepared for the emphasis on women's issues and felt marginalised. We began to think that we had gone horribly wrong.

However, when we marked the examination papers, it became clear that the course had been a success. It allowed the weaker student to pass and the more skilled student to excel. We tried to keep a balance between rewarding subjectivity while discouraging false sycophanticism; between maintaining a degree of theoretical awareness and avoiding sentimentality. There are obvious problems relating to the assessment of such examination responses. New pedagogies require new evaluative techniques and cause one to reconsider old techniques of student assessment. In assignments and in the examination we enter a new contract of shared subjectivities. This presupposes the replacement of a prior contract, one of presumed objectivity, of no subject intrusion in the interaction between the experiencing student and the assessing teacher. This presumed objectivity is epistemologically suspect and may simply be a privileging of certain interpretative routines which have nothing to do with "knowledge", "truth" or "correctness". In short, at moments when the relation of power between students and teachers is subtly renegotiated, the frame holding both parties is a formalised, constrained relationship which begins to lose its solidity, and the notion of "correctness" becomes a site of anxiety rather than creativity. Allowing "subjectivity" is an appeal for a renegotiation of truth and value in the classroom and allows students and teachers to step outside the discursive frame of interpretative legislation, to review the contract.

\section{Pedagogical implic ations for gender theory and the poetry of resistance}

Crucial to my thinking in this paper is that the structures and strictures of interpretative legislation should not be decided in a vacuum, by way of theory, methodology or hypothesis. Rather, the classroom interaction should form the central experience (when distance education is the instructional medium, it is obviously more difficult to sustain this) and methods of assessment should emerge from this experience with the aim of promoting dialogue and encouraging creativity.

My seminars, entitled Women as Other and Women Write Back, took the students through such ideas as the constructed nature of gender, the differences between sex and gender, the instability of identity, the marginalisation of women, women as the object of the gaze and women 
and madness (these topics comprised the first seminar, Women As Other). Following on this, Women Write Back posed such questions as "Do women write differently?" and "Does it matter who speaks?", introducing the concepts of écriture féminine and the possibilities of a female aesthetic, and moving on to black women's voices and the poetry of resistance. I underlined the ideas of female community and collective strength, warning students about the dangers of treating women as an homogenous group, just as they should take care not to essentialize white women as a single and stable category. In an effort to foreground women's differences from each other, I decided to compile my own reader of poetry and included voices from the Caribbean, West Africa, Southern Africa and the United Kingdom. Although the choice of poems was obviously subjective and thus open to criticism, I believe I exposed students to a fair range of women's writing, with perhaps the exclusion of white South African women poets. The poets include Ama Ata Aidoo, Zindzi Mandela, Gcina Mhlophe, Phumzile Zulu, Shakuntala Hawoldar from Africa; Grace Nichols, Merle Collins and Jane King from the Caribbean; Maureen Ismay, Veronica Williams, Carole Stewart and Sista Roots from the United Kingdom; and Margaret Atwood, Nikki Giovanni, Sylvia Plath, Emily Dickinson and Adrienne Rich from the established "canon". It was students' responses to women writers who are not usually included in canonical syllabuses that raised questions for me concerning the poetry of resistance.

Women students across cultural differences responded most positively to the poetry of Grace Nichols, particularly those poems included in the collection The Fat Black Woman's Poems (1984). I included a section from John Berger's Ways of Seeing (1972) in the course material in which he discusses the differences in social presence between men and women:

According to usage and conventions which are at last being questioned but have by no means been overcome, the social presence of a woman is different in kind from that of a man. A man's presence is dependent upon the promise of power which he embodies. If the promise is large and credible his presence is striking. If it is small or incredible, he is found to have little presence. The promised power may be moral, physical, temperamental, economic, social, sexual - but its object is always exterior to the man. A man's presence suggests what he is capable of doing to you or for you. His presence may be fabricated, in the sense that he pretends to be capable of what he is not. But the pretence is always towards a power which he exercises on others.

By contrast a women's presence expresses her own attitude to herself, and defines what can and cannot be done to her. Her 
presence is manifest in her gestures, voice, opinions, expressions, clothes, chosen surroundings, taste - indeed there is nothing she can do which does not contribute to her presence. Presence for a woman is so intrinsic to her person that men tend to think of it as an almost physical emendation, a kind of heat or smell or aura

(Berger, 1972:45).

Basing their observations on Berger's analysis of the promise of male power, students discussed Nichols's poetry enthusiastically in terms of how she invites the gaze, even provokes it, how the persona's attitude in the poems is refreshingly liberated from stereotypical ideas about the female body, and how she seems to exude the promise of female power:

\section{Invitation}

If my fat

was too much for me I would have told you

I would have lost a stone or two

I would have gone jogging even when it was fogging I would have weighed in sitting the bathroom scale with my tail tucked in

I would have dieted more care than a diabetic

But as it is

I'm feeling fine

feel no need

to change my lines

when I move I'm target light

Come up and see me sometime

Come up and see me sometime

Come up and see me sometime

My breasts are huge exciting

amnions of watermelon your hands can't cup

my thighs are twin seals fat slick pups

there's a purple cherry

below the blues

of my black seabelly 
There's a mole that gets a ride each time I shift the heritage of my behind

Come up and see me sometime

(University of South Africa: Tutorial Letter 103/2000:169).

As Barbara Harlow (1987) says, resistance literature calls attention to itself as a political and politicized activity. Although Harlow does not discuss resistance in terms of a specifically gendered response, her views are pertinent and may be extended beyond what we usually designate as "political". Grace Nichols calls attention to herself (or more accurately, to the woman in her poem) defining her presence as sexually powerful (exuding "an almost physical emendation" [Berger, 1972:45]). She turns Berger's idea - "men act and women appear" - on its head. In this and other poems, Nichols mocks the idea of woman looking at herself with the eyes of the male surveyor and in so doing, resists the power of the active male spectator:

To be naked is to be oneself.

To be nude is to be seen naked by others and yet not recognised for oneself. A naked body has to be seen as an object in order to become a nude. (The sight of it as an object stimulates the use of it as an object.)

Nakedness reveals itself. Nudity is placed on display.

To be naked is to be without disguise.

To be on display is to have the surface of one's own skin, the hairs of one's own body, turned into a disguise which, in that situation, can never be discarded. The nude is condemned to never being naked. Nudity is a form of dress (Berger, 1972:50).

In "Invitation", the woman in the poem is both naked and nude. She both wears her body as a disguise and yet is herself. She insists that the viewer recognises her body as herself and on display simultaneously. In doing so, she disrupts the conventions of the male gaze by demanding it. There is a powerful sense here of the body operating as signifier, of the body as both a site of meaning and an instrument of knowing. When asked to apply Berger's views to Sylvia Plath's "Mirror" and Grace Nichol's "Invitation", by far the majority of students seemed to identify with the obsessive concerns about ageing portrayed in "Mirror", but aspired to the attitudes conveyed by Nichols. A very few expressed anxiety, even disgust, about the open display of and pride in the female body conveyed in "Invitation" and elsewhere in the course material:

Looking at the course material, I could not hide my feelings of disgust. As a black woman who, because of cultural conditioning, 
has been an oppressed and repressed breeding machine, I could not hide my anger ... When I first read the poems I could not hide my surprise when I learnt that even women from other cultures were dominated by their men. In our culture (that is the black culture) it is the norm. As women we feel awkward to speak about it, we take it as part of womanhood. I really identified with the women who wrote back, because I could not write any protest literature since I have been brought up to be submissive.

This course has been my mouthpiece or an extension of my mouth, reaching out to those women who are in the same predicament. (Unedited examination answer.)

The response of this student and others like her, raised questions for me about social taboos and the way in which African writers and readers seem to be conditioned by a culture of respectability in which social taboos define the limits of decency. The student just quoted shows an interesting progression from disgust to anger to surprise. Her repetition of the phrase "I could not hide ..." hints at years of suppression and may have been occasioned by "The Laugh of the Medusa" by Hélène Cixous which was also included in the study material:

I wished that that woman would write and proclaim this unique empire so that other women, other unacknowledged sovereigns, might exclaim: I, too, overflow; my desires have invented new desires, my body knows unheard-of songs. Time and again I, too, have felt so full of luminous torrents that I could burst ... And I, too, have said nothing, showed nothing; I didn't open my mouth, I didn't repaint my half of the world. I was ashamed ... Who, feeling a funny desire stirring inside her (to sing, to write, to dare to speak, in short, to bring out something new) hasn't thought she was sick? Well, her shameful sickness is that she resists death, that she makes trouble (Cixous, 1991:335).

Compare the response of the following student who has obviously absorbed the study material effectively:

Poetry started to matter to me again when I realized that I had to adopt a resistant mode of reading, that neither reading nor writing is an objective activity. Both as reader and as writer my situation is plural, fragmentary and transient, and this realisation brought home to me the importance of self-reflexiveness. It became clear to me that I had to read/to write myself into the text and that the challenge lies in symbolizing it meaningfully for myself ...

Particularly inspiring are poems written by black women who refuse to be victims (if they had written themselves as victims they would merely have defined themselves in relation to men as oppressors all 
over again - cf. Nichol's Of course when they ask for poems about the 'realities' of black women?- ) ... As I see it then, our task lies in re-imagining women, not only in their differences from one another. Our attempt should not be about the simple valorization of all things female (i.e. a mere reversal of patriarchal norms) but about a shift towards a much more inclusive system of valorization, where objectification of any other is a thing of the past. (Unedited response to examination.)

And this student chose to write a poem, under exam conditions:

\section{Blond-haired white virgin}

My white boyfriend

He says to me

don't you

long to be

a blond-haired

white virgin?

And this question

it shocks me so

Because no

I have never

ever

wanted to be

a blond-haired

white virgin.

My boyfriend's gone long ago

yet his words

they echo so

over and over

in my mind.

(Here is my poem. It's personal. It's true. I was influenced by the black women writers)

Students responded most readily to a sense of active resistance. As Mary deShazer (1994:183) observes (quoting Frank Meintjies: 'a new language is needed, "one imbued with the promotion of life, a celebration of democracy building on creative grassroots energy"'), resisters are not always victims and it is the victim ideology that readers are most bored 
with. Significantly, it was not only female students who responded positively to the poetry:

The poetry of African/Caribbean writers has had a profound effect on me as an African male - reared on the comforting illusion that the male is 'Boss'. The poems by these writers occasion themselves as indictments because they question the validity of the hegemonic binary polarities which have genderized and feminized even innocuous biological gestures ... I came to realise that the anguished 'l' of the women poets is not exclusively the selfish 'l' (notwithstanding the poetry of Sylvia Plath) but a comradely 'l', a communal grief by women who are invariably elided in hegemonical discourse. This course was for me a journey which occasioned a profound change in my callousness towards women, my obdurate indifference to women writers, and has provided ample background and 'fertile' ground (note that I use 'fertile' as a subversive strategy) to engage peers on what should determine relations between men and women and the relation of women to themselves. (Unedited examination response.)

In this sense, and using the old terminology from the women's movement, most female students used Nichols as a role model while a few (a very few) male students found that their attitudes were changed by reading women's poetry. 4 . Female students discovered in such poets as Shakuntala Hawoldar an echo of their feelings of effacement as well as an empowering vision for change.5

\section{5. "Rape"}

As gratifying and humbling (for me as examiner, privy to students' personal communications, often painful, and intensely aware that I was being put into a position of trust) as these responses in the Gender section are, those occasioned by a poem included in the section on voyeurism and desire are perhaps even more significant. This poem by Jane Cortez was found in an anthology of Postmodern American Poetry (Hoover, 1994) and placed in the seminars along with Walt Whitman on poetry, desire and voyeurism:

4 One male student told us that this course had made him see his mother for the first time as a woman with needs of her own. Most male students chose to respond to Ivan Rabinowitz's seminars on Poetry, Desire and Spectatorship and to the poetry of Walt Whitman.

$5 \quad$ See Appendix. 


\section{Rape}

Inez Garcia, Joanne Litte - Two Victims in the 1970s

What was Inez supposed to do for the man who declared war on her body the man who carved a combat zone between her breasts Was she supposed to lick crabs from his hairy ass kiss every pimple on his butt blow hot breath on his big toe draw back the corners of her vagina and hee haw like a California burro

This being war time for Inez she stood facing the knife the insults and her own smell drying on the penis of the man who raped her

She stood with a rifle in her hand doing what a defence department will do in times of war

And when the man starting grunting and panting and wobbling forward like a giant hog She pumped lead into his three hundred pounds of shaking flesh

Sent it flying to the Virgin of Guadalupe then celebrated day of the dead rapist punk and just what the fuck else was she supposed to do?

And what was Joanne supposed to do for the man who declared war on her life Was she supposed to tongue his encrusted toilet stool lips suck the numbers off of his tin badge choke on his clap trap balls squeeze on his nub of rotten maggots and sing god bless america thank you for fucking my life away

This being wartime for Joanne she did what a defence department will do in times of war and when the piss drinking shit sniffing guard said I'm gonna make you wish you were dead black bitch come here 
Joanne came down with an ice pick in

the swat freak motherfucker's chest

yes in the fat neck of that racist policeman

Joanne did the dance of the ice picks and once again

from coast to coast

house to house

we celebrated the day of the dead rapist punk

and just what the fuck else were we supposed to do

(from Postmodern American Poetry, Mazzaro, 1980).

We included this poem in the examination with the comment: "'Speak' to your examiners about this poem". By far the majority of students responded positively to the violent language and the sense of fighting back in the poem. Several students confided in the examiners that they had been raped or abused; that this was the first time that they had been able to speak about their experience. These students commented on the power of the poem to induce both pain and relief, and it was obvious that writing about the poem was a cathartic experience. Out of 450 students who wrote the paper, only a handful complained about the language (remember that they chose to answer on this poem out of a wide range of questions) but admitted that it was effective. Several male students discussed the effect that the f-words in an examination had on them; others wrote their own versions of the poem. What was so striking about students' responses in general was the sense of energy conveyed in their writing (under exam conditions) and their search, not always successful, for new ways of writing about poetry. The sense of liberation was fascinating to observe and the effect it had on the examiners was electric. For the first time in twenty-two years of marking exam papers, I looked forward to my day's quota, usually reading even the essay that I was not supposed to mark. Bearing in mind that three examiners had to mark 900 questions, it was surprising that this interest did not wane.

Here are some responses to "Rape":

Examiner, I need you to know between you and me this poem may have changed me. It freed me from the restraints of silence, of accepting blame and feeling responsible. It was not my fault. I've heard that a thousand times before, but the difference this time is that I know it was not my fault ... You have helped me deal (well sort of anyway) with one of the most painful experiences ever, both emotionally and physically. I am grateful to Jayne Cortez for pulling me out of the mess I was wallowing in, that of blame and self-pity, but as you chose the poem and the question, my sincere gratitude to

6 The other course mentioned, that is Intertextual Readings, covered works of fiction. 
you the examiner for opening my eyes and my mind. (Unedited response from a female student who told her examiners that this was the first time she had spoken about her rape (7)

A male student on "Rape":

This is not a poem you speak about directly after you have read it or hear it or had it read at you. If you can speak directly after you are a Kelvinator fridge. You don't clap, you don't whistle or turn and nod your head at a friend - you stare. You stare straight ahead as your soul sits panting in a corner, pumped up with adrenalin, ready at a lightning bolt's heartbeat to strike and kill any 'dump-punk motherfucker rapist'.

It is intoxicating scruff of the neck and kick it in the butt poetry. It is poetry's political charisma, you won't deny it, you'll cheer silently like all the others, 'just what the fuck else' are you supposed to do? Analyse it? 'This being exam time for Robert, he did what students will do in times of test' I don't think so! it would belittle the poem, it would be like laughing at Inez and Joanne.

If you can't analyse this poem, if you can't write a four page essay on its metaphors and similes what is it doing in a university syllabus? Does every poem need to be analysed line by line? (Unedited examination answer.)

Yes, what is a poem like this doing in a university syllabus? What is the pedagogical aim in exposing students to explosive material? Why is it necessary to include oppositional poetry in a university curriculum?

I have gained as a teacher of literary studies by following the ideas put forward by Stanley Aronowitz and Henry Giroux, particularly those pertaining to cultural politics and the role of teachers as public intellectuals. Indeed, the ethos behind Changing Worlds, Changing Texts was very close in aim to the following:

... the relationship between knowledge and power is analyzed as part of a wider effort to define schools [and universities] as places where a sense of identity, worth, and possibility is organized through the interaction among teachers, students, and texts. Accordingly, schools are analyzed as places where students are introduced to particular ways of life, where subjectivities are produced, and where needs are constructed and legitimated (Aronowitz \& Giroux, 1991:87).

$7 \quad$ We asked permission from students to quote from their papers for research purposes. 
The members of the course team certainly did not set out to design a curriculum with the aim of producing subjectivities. At best, this was an unexpected outcome of the course design. So, although critical pedagogy was not part of the original conceptual framework, it transpired as precisely the methodology at work. We were working instinctively towards allowing students the freedom to find out for themselves what poetry could mean in their lives. What we did not want to produce was a group of students mouthing polite responses and constrained by what they thought we wanted to hear. In lieu of the correct response, students had no choice but to turn to their own subjectivities and speak from a sense of their own cultural framework. A poem such as "Rape" places an obligation on students not to respond conventionally. It prevents students and teachers from slipping comfortably into well-worn habits, traditional contracts, familiar and unchallenging discursive relationships. It takes from them the convenient tools with which students usually "analyse" poetry. In the absence of such tools, students wrote with verve and surprising innovativeness. They were in the Barthesian sense, becoming active producers of the texts instead of passive consumers.

Again, Aronowitz and Giroux (1991:89) supply the necessary theoretical underpinning for what we were doing:

Textual authority ... is developed as part of a wider analysis of the struggle over culture fought out at the levels of curriculum knowledge, pedagogy, and the exercise of institutional power. In addition we argue for the necessity of developing a politics and pedagogy of voice as part of a theory of curriculum that opens up texts to a wider range of meanings and interpretations, while simultaneously constructing student experience as part of a broader discourse of critical citizenship and democracy.

My own aim has been to open up texts (poetry in particular) to the broader discourse of a critique of gender relations within a dominantly patriarchal society and to listen with respect to students' sense of who they are and how they constitute themselves as revolutionary or oppositional subjects. By engaging with literary studies, feminist theory, poststructuralism and critical pedagogy, students are encouraged to think about such issues as:

- how I situate myself as a reader

- how I come to think about myself as either male or female and what this means

- the conditions under which women writers are silenced or silence themselves 
- the possibilities of a female aesthetic

- the limits of oppositionality

- women's bodies and the male gaze

Rather than prescribe how women should write, therefore, I am more comfortable in my capacity of a teacher of literary studies and gender theory, in suggesting ways in which teachers can help produce an oppositional awareness of and in revolutionary subjects in the dual sense of subjects as topics or objects of knowledge, and as subjectivities.

\section{Conclusion}

The curriculum transformation attempted by some of the members of the Department of English Literary and Language Studies at Unisa raises interesting questions concerning what and, more importantly, why we teach. What is the purpose of teaching poetry? How can it be taught? In reconceptualising our role as public intellectuals (see Aronowitz \& Giroux), we have had to recognise the equally important role of students as part of a transformative process of knowledge and power. By allowing poems and theoretical discourses to speak to students without significant mediation by lecturers, students have found their own voice and their own perspective on such issues as gender inequity, racism, appropriation and spectatorship. Their voices have been heard in assignments, in examination questions and in poetry offered by students. We were intentionally trying to get away from the empty, meaningless academic discourse we all slide into when the subjects we teach have become over-familiar, boring, or meaningless. We used to talk to each other in our study guides. Now we talk to students. And they talk back:

I'm not quite sure when poetry started to mean something to me. I think it was perhaps around the time of Standard six: 'Algebra: An Introduction'. Father is getting a little annoyed now. He can't make it any clearer, really. Tempers flare, and the spotty adolescent is the first to explode by hurling the foul blue Math book across the diningroom. Father responds rationally. This is not surprising as he has always been aware of the need to control our perhaps more illogical traits. The boy retires to his room with its death rattle glam-rock soundtrack and magnificent orange Adidas trainers and mad-nude paintings of Frida Kahlo with nails where her nipples might once have been. ('His head is stuck in that bloody poetry book again, Mother'.) Obviously I'm the boy. I responded then, as I do now, to passion in poetry. My father has learnt to live with my utter irrationality and disdain for any form of logic. One cannot rationalize or explain why one likes poetry, surely? I believe it is just there, inside you; highly individual. It is, like most things, completely 
subjective. I enjoyed Changing Worlds, Changing Texts (well, most of it) because it acknowledged this deviance and subjectivity, legitimised the debasement of objectivity ...

'The act of writing poetry changes those who write; the act of reading poetry changes those who read'. Yes, certainly. Reading the poetry this year has made me a writer. Those repressed urges to create have been purged, destroyed as I realised that I too can be whatever I want to be, whenever I want. I can have a Belsen in my belly like Sylvia Plath: I can leer and theorize like John Donne did; I can lie in love with life's possibilities in a Paris high-rise like Allen Ginsberg did.

I would not have written an essay like this a year ago. Such a wilfully unacademic catharsis would have been beyond me. Perhaps it is selfish, this solipsistic immersion in the self, seeing what only I want to see. I was happy with Poetry this year because there were poems I enjoyed reading. The important thing though is that the course was fairly inclusive. Only black men were unrepresented (this isn't necessarily a bad thing; there are enough powerful black men in everyday South Africa, just as there were enough powerful white men a few years ago). (Unedited extract from an examination answer.)

With the experience of assessing responses to "Rape" came the realization that the distinction between older and new pedagogies, so often characterised as the shift from objectivity to subjectivity, may obscure rather than reveal real issues and that the terms of this objective/subjective opposition are falsely constituted. By presenting themselves as objective, established pedagogies secure their participation in truth and knowledge beyond mere individual experience. Moreover, this epistemological move relegates the new subjective pedagogy to the merely discrete and local. But the prevailing conception of knowledge in this instance is false because the older pedagogy has no privileged relation to truth. Its protocols have simply bled out the possibility of a genuine, felt response in the name of objective knowledge. Established literary criticism simply entails participation in a special kind of language game. The new "subjective" pedagogies aim to reinsert the human in the idea of human knowledge.

So what now? The course has been abandoned; it has had its day. We need to consider whether the new directions indicated here remain viable avenues for the teaching of women's poetry in South Africa. I tentatively suggest that women as writers and readers look to crossing certain limits and expand the idea of resistance as opposition, resistance as grumbling, resistance with decency, to resistance as erotica, resistance 
of the body, resistance as activity, resistance as unruly discourse, above all to the revolutionary potential of poetry itself. The effect will resonate upon readers and writers alike. As Audre Lorde (1984) says:

Poetry is not a luxury. It is a vital necessity of our existence. It forms the quality of light within which we predicate our hopes and dreams toward survival and change, first made into language, then into idea, then into more tangible action (Sister Outsider).

\section{Bibiliography}

Aronowitz, Stanley \& Giroux, Henry. 1991. Postmodern Education: Politics, Culture and Social Criticism. Minneapolis : University of Minnesota Press.

Berger, John. 1972. Ways of Seeing. London: Penguin.

Brodkey, Linda. 1989. On the Subject of Class and Gender in "The Literacy Letters". College English, 51(2):125-126.

Cixous, Hélène. 1991. The Laugh of the Medusa. In: Warhol R. \& Herndl, P. (eds.) Feminisms: an Anthology of Literary Theory and Criticism. New York : Rutgers. p. 347-362.

De Kock, L., Rabinowitz, I.A., Ryan, P.D., Simpson, M.H.D. (eds.) 2000. Changing Worlds, Changing Texts. Tutorial Letter 102 for 20000. University of South Africa.

DeShazer, Mary. 1994. A Poetics of Resistance: Women Writing in El Salvador, South Africa, and the United States. Ann Arbor : The University of Michigan Press.

Harlow, Barbara. 1987. Resistance Literature. New York : Methuen.

Lorde, Audre. 1984. Sister Outsider: Essays and Speeches. New York : Crossing Press.

Mazzardo Jerome. 1980. Postmodern American Poetry. Urbana : University of Illinois Press.

Nichols, Grace, 1984. The Fat Black Woman's Poems. London : Virago.

\section{Key concepts:}

course design

distance education.

feminist pedagogy

teaching poetry

teaching women's poetry

\section{Kernbegrippe:}

afstandsonderrig feministiese pedagogiek

kursusonderrig poësie, onderrig van

vrouepoësie; onderrig van 
Appendix $1 *$

\section{Of course when \\ they ask for poems \\ a bout the "rea lities" \\ of black women}

What they really want

at times

is a specimen

whose heart is in the dust

5 A mother-of-sufferer trampled, oppressed they want a little black blood undressed and validation

10 for the abused stereotype already in their heads

Or else they want a perfect song I say I can write

15 no poem big enough to hold the essence of a black woman or a white woman or a green woman

20 And there are black women and black women like a contrasting sky of rainbow spectrum

Touch a black woman

25 you mistake for a rock and feel her melting down to fudge

Cradle a soft black woman and burn fingers as you trace

30 revolution beneath her woolly hair

And yes we cut bush to clear paths for our children
35 and yes

we throw sprat to catch whale and yes, if need be we'll trade

40 a piece-a-pussy than see the pickney dem in de grip-a-hungry-belly

Still, there ain't no easy-belly category

45 for a white woman or a black woman or a green woman

And there are black women strong and eloquent

50 and focused

And there are black women who somehow always manage to end up frail victim

And there are black women

55 considered so dangerous in South Africa they prison them away

Maybe this poem is to say, that I like to see

60 we black women

full-of-we-selves walking

Crushing out

with each dancing step the twisted self-negating

65 history

we've inherited

Crushing out with each dancing step.

(Grace Nichols)

These poems are taken from the course Reader, Tutorial Letter 103/2000. University of South Africa. 


\section{Appendix 2}

\section{To Be a Woman}

To be a woman,

a shadow without form,

extinguished by sunlight,

Wombing meaningless men

in the endless chain of need;

To be worn on rainy days,

like colourless old shoes

groping between pots and pans

eyes in steam,

Streaming more than onion-tears;

to be a woman,

characterless like bamboo stalks,

to be scissored to shape,

a hedge against odd weather

and when asleep to fly

untrammelled like a bird,

to exult in the open air,

tossing between oceans and clouds

dreaming of trees kissed by the sun,

while their gnarled roots sink into the earth;

then to return with the weighted womb,

like a boomerang -

to believe that shadows have existence.

(Shakuntala Hawoldar)

\section{Mirror}

I am silver and exact. I have no preconceptions.

Whatever I see I swallow immediately

Just as it is, unmisted by love or dislike.

I am not cruel, only truthful -

The eye of a little god, four-cornered.

Most of the time I meditate on the opposite wall.

It is pink, with speckles. I have looked at it so long

I think it is a part of my heart. But it flickers.

Faces and darkness separate us over and over.

Now I am a lake. A woman bends over me,

Searching my reaches for what she really is.

Then she turns to those liars, the candles or the moon.

I see her back, and reflect it faithfully.

She rewards me with tears and an agitation of hands.

I am important to her. She comes and goes. 
Each morning it is her face that replaces the darkness. In me she has drowned a young girl, and in me an old woman Rises toward her day after day, like a terrible fish.

(Sylvia Plath) 
